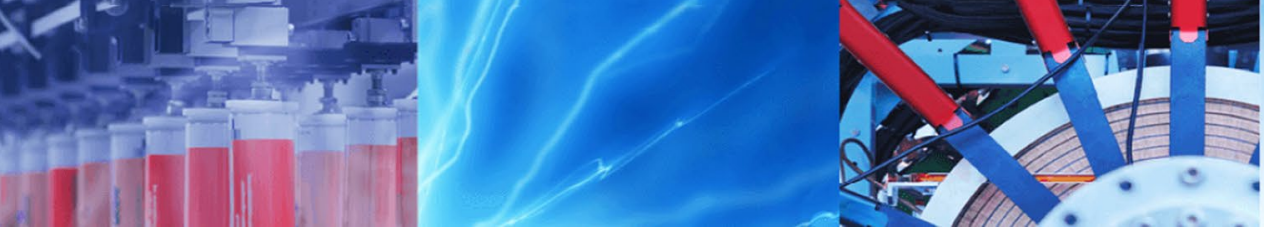

Research Article

\title{
Electromagnetic-induction and spatial analysis for assessing variability in soil properties as a function of land use in tropical savanna ecosystems
}

\author{
Melissa A. Atwell ${ }^{1}$ - Mark N. Wuddivira ${ }^{2}$
}

(c) Springer Nature Switzerland AG 2019

\begin{abstract}
Identifying spatial patterns in the variability of key soil properties to delineate the extent of land degradation could ensure efficient management of natural resources in terrestrial ecosystems. However, little is still known in tropical savannas that are subjected to indiscriminate land use. We evaluated the soil variability at the plot-scale in a terrestrial tropical ecosystem subjected to varying land use/land cover management to assess the impact of uncontrolled land uses on the soil natural capital. The non-invasive, time/cost efficient electromagnetic induction (EMI) technique was assessed for its potential, to determine the effect of land uses on soil spatial variability in a changing land use gradient from pristine land use/land cover conditions. The investigation was carried out in a natural tropical ecosystem in Aripo, Trinidad with soils of predominantly ultisols order and influenced by anthropogenic disturbances. EMI-based apparent electrical conductivity (ECa) measurements were obtained at two depth ranges (shallow $=0-0.5 \mathrm{~m}$ and deep $=0-1.5 \mathrm{~m}$ ). Soil properties showed that the residential anthropogenic land use had a higher mean apparent electrical conductivity shallow $\left(E C a_{s}\right)$ value $\left(E C a_{s}=305.9 \mathrm{mS} / \mathrm{m}\right)$ than all other land uses. Higher $E C a_{s}$ values in the residential site suggest that human influences can increase the magnitude of electrical conductivity, which can alter the biogeochemical cycles of the soil affecting services provided by the ecosystem. Also anthropogenic land use/land covers exhibited lower coefficient of variation for soil texture (silt and clay) than natural land uses, indicating lower sensitivity of soil texture to land use due to the mixing of soils, which encourages uniformity in anthropogenic sites. Soil texture dominated the $\mathrm{ECa}_{\mathrm{s}}$ signal in the natural land use/land covers with the relationship between $\mathrm{ECa}_{\mathrm{s}}$ and silt in the Forest $(\mathrm{r}=0.486)$ and Grass $(r=-0.495)$ significant at $P<0.05$. Soil texture showed greater sensitivity to land use in natural sites than in anthropogenic sites. The dominance of soil texture in the natural sites indicates that in tropical soils that are predominantly light textured (clay content $<21 \%$ ), silt content controls the EMI signal, which can become of low influence following disturbance. The magnitude of electrical conductivity can increase due to human influences. This can alter the biogeochemical cycles of the soil, affecting services provided by the ecosystem.
\end{abstract}

Keywords Apparent electrical conductivity $\cdot$ Land cover $\cdot$ Soil management $\cdot$ Soil variability

\section{Introduction}

Soil degradation as a result of uncontrolled land use/land cover activities is the leading cause of ecosystem decline, reaching severe levels in certain islands of the Caribbean
[71]. The increase in uncontrolled land activities as a result of deforestation, urban sprawl, industrialization and agriculture has undermined the productive capacity of the terrestrial ecosystem [9]. The most critical pillar of the ecosystem that is negatively affected is the soil natural

\footnotetext{
$\triangle$ Melissa A. Atwell, melissa.atwell@sta.uwi.edu| ${ }^{1}$ Department of Geography, Faculty of Food and Agriculture, University of the West Indies, St. Augustine, Trinidad. ${ }^{2}$ Department of Food Production, Faculty of Food and Agriculture, University of the West Indies, St. Augustine, Trinidad.
} 
capital. The productivity of the soil natural capital in general depends on the natural variability of soil properties. Uncontrolled land use/land cover activities decrease natural variability and undermine the productivity of the soil [66]. Human impacts have been shown to increase or decrease soil variability $[14,74]$. As a result, it is important to take into account the variability of soil properties in its dynamic forms as they are necessary for site specific land management. An understanding of the soil variability from natural to anthropogenic land uses/land covers can better explain soil function processes and subsequent sustainable management.

Geophysical soil sensing to assess soil spatial variability has been documented over the last four decades [17, $27,37,42,65,68]$. Determining soil variability as affected by human-induced land activities using electromagnetic induction (EMI)-based apparent electrical conductivity (ECa), can effectively discriminate the magnitude of soil variability. Conversely, although ECa variability research in savanna ecosystems is sparse with studies conducted in California [55, 56] and Texas [59], no evidence of the impacts of land cover change on soil variability in tropical savannas is provided to the best of our knowledge.

Tropical savannas are important because of their vast biodiversity of flora and fauna, many of which are endemic. However, they are regularly over-exploited for example, for food and growing urbanization. Uncontrolled changes (unapproved change to meet needs of surrounding communities) in land use/land cover which is often not based on land planning, give rise to the disruption of soil-vegetation systems responsible for the preservation of habitats. Some land use types have been known to influence changes in the top soil [3], negatively affecting soil quality such as water holding capacity, nutrient content and cation exchange capacity. Consequently, anthropogenic land use/land covers such as residential, quarrying and agriculture encroaching into natural areas can alter the savannas' ecosystem. The long history of changes in land covers have resulted in lowering of the soil productive capacity and depletion of soil natural capital [38]. In Aripo Savanna, Trinidad, Atwell et al. [9] indicated that professional judgment and local knowledge have shown that with increased human impact, greater deterioration in the soil health occurs. Therefore, greater bulk densities, lower porosities, lower aggregate stability, lower species diversity, and shallower top soils were found in anthropogenic influenced areas than natural areas. However, no systematic study has hitherto been conducted to assess the spatial dynamics of soil properties in the savanna ecosystem as a result of the varying anthropogenic practices. Therefore, understanding the variability of soil properties within a land use and from natural to anthropogenic land use/land cover systems is critical for optimization of management decisions for restorative efforts and sustainable use of the savanna ecosystem.

Apparent electrical conductivity as a means of assessing soil properties was first used for the determination of soil salinity [51,52]. Due to its reliability as an indicator of the concentration of soil solutes, continuous developments have arisen in the form of time domain reflectometry (TDR) for the simultaneous measurements of properties such as volumetric water content [16, 53, 62]. Relationships between ECa and water content and ECa and soil solutes as well as several other edaphic properties provides justification for using the ECa signal as a proxy for soil properties.

In addition, ECa has also been found to have relationships with a variety of anthropogenic properties such as leaching fraction, irrigation and drainage and compaction [15], making it ideally suited to assess the effects of land use management. Apparent electrical conductivity measurements as an indicator of soil quality can be used to determine site specific management zones in precision agriculture $[20,43]$.

Fluctuations of ECa are generally in response to different soil physicochemical properties such as salinity, bulk density/porosity [49], clay content [63, 72], water content [34], carbon content [40]. Under humid tropical conditions, ECa is found to be influenced by temporal changes in soil moisture content for example soil-water repellency [11], spatial variation of clay-silt mineral content $[8,72]$ and soil solution electrical conductivity (ECe) [7]. Variations in ECa (Dualem EC meter) in non-saline soils, however, are primarily a function of soil texture, moisture and cation exchange capacity $[11,20,44,60]$. This is also observed in tropical savannas where structural and compositional attributes of the soil are often described in relation to rainfall and soil texture $[69,72]$.

Fitzjohn et al. [26] reported that traditional methods of soil survey can be problematic in terms of sampling, data interpretation and extrapolation. They are also time consuming, invasive and not cost effective and thus may not always be the most suitable method in rugged environments. Modern methods such as EMI have been used by researchers in different environments $[28,33,58]$. More specifically, EMI as a measure of variation in soil properties to collect spatially exhaustive data has been used by researchers in humid tropical land use environments for example; Bréchet et al. [11] in both teak and native forests, Atwell et al. [7] in wetlands and De Caries et al. [19] in a Cocoa plantation, making it a suitable instrument to be employed as it expedites site characterization and increase accuracy while combining sufficient spacing, extent, and support [10] to capture the small-and large-scale variability of soil properties across a field site [55]. 
The DUALEM-1S meter is one such EMI meter capable of measuring two depths of the soil, the upper depth at $0-0.5 \mathrm{~m}$ and the lower depth at $0-1.5 \mathrm{~m}$ of the soil [1]. Since the soil is affected by land use/land cover and climatic factors at its surface $(0-0.5 \mathrm{~m})$ and by the clay pan and parent material in deeper depths (0-1.5 m), comparing the soil variability at these two layers by quantifying the effects in the soil, provides an understanding of the dynamics of within-field variability of the soil physicochemical properties. Although land use can positively affect soil variability and functions, anthropogenic land cover change affects surface soil variability due to reduction in microbial biomass, disruption of the formation of microaggregates, reduction of organic matter and accelerated erosion. At the deeper depths of the soil, land cover can change the recycling of plant nutrients and alter carbon stabilization affecting soil quality and contribute to soil variability.

While there has been research on the influence of land use/land cover change on soil quality (e.g., [13, 25, 32, 47]), limited research has been conducted on the within-field variability information necessary for the development of good soil quality management strategies of tropical soils. In spite of the fact that ECa does not hold a direct relationship with land use/land covers, it depends directly on the range of soil properties which can in themselves be influenced by land covers. Therefore, it is hypothesized that ECa signals in humid tropical soils can vary depending on, among others, the prevailing land covers. The objectives of our study were to: (1) quantify soil properties in the Aripo savannas under different land uses/land covers (2) determine the effect of soil properties on electromagnetic signal within various land use/land cover types; (3) investigate the spatial heterogeneity of soil properties as influenced by land use/land cover change; (4) discriminate the sensitivity of soil quality factors to different land uses/ land covers using the EMI.

\section{Materials and methods}

\subsection{Location and climate}

The Aripo savannas lies in the North Central region of Trinidad $\left(10^{\circ} 30^{\prime} 35^{\prime \prime} \mathrm{N}, 61^{\circ} 12^{\prime} 0^{\prime \prime} \mathrm{W}\right)$ bordered by the Valencia river to the north and the Aripo river to the west. The climate is humid tropical with distinct wet (January to May) and dry (June to December) seasons. The average annual rainfall ranges from 2400 to $2600 \mathrm{~mm}$ in response to seasonal fluctuations. The monthly temperatures range from 22.7 to $31.3^{\circ} \mathrm{C}$ with relative humidities of $60 \%$ and $75 \%$ in dry and wet season respectively (EMA [24]). Like most tropical savannas, the water availability in the Aripo savannas is seasonal. During the dry season the surface fine sandy to silty soils severely dry out causing vegetation to suffer from drought. In the wet season, due to water logging, the savannas are periodically submerged causing physiological drought to vegetation [4]. Vegetation types found in the Aripo savannas include grass, sedge, palm and marsh forests.

In the past, the savannas (Fig. 1) have been covered much more extensively by marsh forest, however, due to activities which include timber harvesting, quarrying, agriculture and use as a US military base (Table 1), many parts of the savanna ecosystem have been devastated. Our study area consisted of five study sites, four within the scientific zone of the Aripo savanna, and one outside. The sites were selected due to differences in land use and land cover that currently take place within the Aripo savanna protected area. These include: (1) unplanned residential lands due to squatter settlements (Size $=\sim 34 \mathrm{~m} \times 47 \mathrm{~m}$ ) located in previously forested land use $\left(10^{\circ} 36^{\prime} 09.13^{\prime \prime} \mathrm{N}\right.$, $61^{\circ} 12^{\prime} 34.96^{\prime \prime} \mathrm{W}$ ), (2) abandoned quarry land (Size $=\sim 75 \mathrm{~m}$ $\times 58 \mathrm{~m}$ ) located in a previously grassland land use/land cover $\left(10^{\circ} 36^{\prime} 17.65^{\prime \prime} \mathrm{N}, 61^{\circ} 12^{\prime} 24.04^{\prime \prime} \mathrm{W}\right)$, (3) natural forest land use/land cover (Size $=\sim 96 \mathrm{~m} \times 79 \mathrm{~m})\left(10^{\circ} 36^{\prime} 07.60^{\prime \prime} \mathrm{N}\right.$ $\left.61^{\circ} 12^{\prime} 25.11^{\prime \prime} \mathrm{W}\right),(4)$ natural grassland land use/land cover $($ Size $=172 \mathrm{~m} \times 97 \mathrm{~m}),\left(10^{\circ} 35^{\prime} 38.94^{\prime \prime} \mathrm{N}, 61^{\circ} 12^{\prime} 16.15^{\prime \prime} \mathrm{W}\right)$ and (5) unsustainable agricultural land use due to poor farming practices by unlawful squatter settlers (Size $=82 \mathrm{~m} \times 34 \mathrm{~m}$ ) located in a previously forested land cover $\left(10^{\circ} 38^{\prime} 43.05^{\prime \prime} \mathrm{N}\right.$, $\left.61^{\circ} 11^{\prime} 51.80^{\prime \prime}\right)$. The soils within this region are Ultisols belonging to Aripo fine sand, Long Stretch fine sandy-clay and Valencia fine sand soil series developed on silty clays, gravelly clays and sand parent materials. The topography of the area is generally flat with a microtopography broken up into hummocks in some places. The savanna is situated on old alluvial terraces from the Pleistocene age 35-40 m above sea level. Weathering of alluvial terraces form a hardened clay pan layer $15-30 \mathrm{~cm}$ down the soil profile. This layer may come to the surface at different parts of the savanna significantly affecting drainage of soils in the area.

\subsection{Electromagnetic induction surveys}

Electromagnetic induction (EMI) surveys were carried out to map the bulk soil electrical conductivity (ECa) of the five study sites non-invasively using the DUALEM-1S (Dualem, Milton, ON, Canada), a field computer (Archer Ultra Rugged Field PC, Juniper Systems) and a GPS-BT GPS receiver (Royal Tek, Kuei Shan). The instrument is highly portable, small enough to be carried by one person and its mode of operation is less time consuming than traditional soil survey methods [30]. The instrument comprises of a transmitter coil and two receiver coils. Once the transmitter coil becomes energized, a time varying magnetic field arises. 
Fig. 1 Map of scientific zone showing the locations and electro-magnetic pathways surveyed for the 5 field sites a agriculture, $\mathbf{b}$ quarry, $\mathbf{c}$ residential (d) forest and (e) grassland

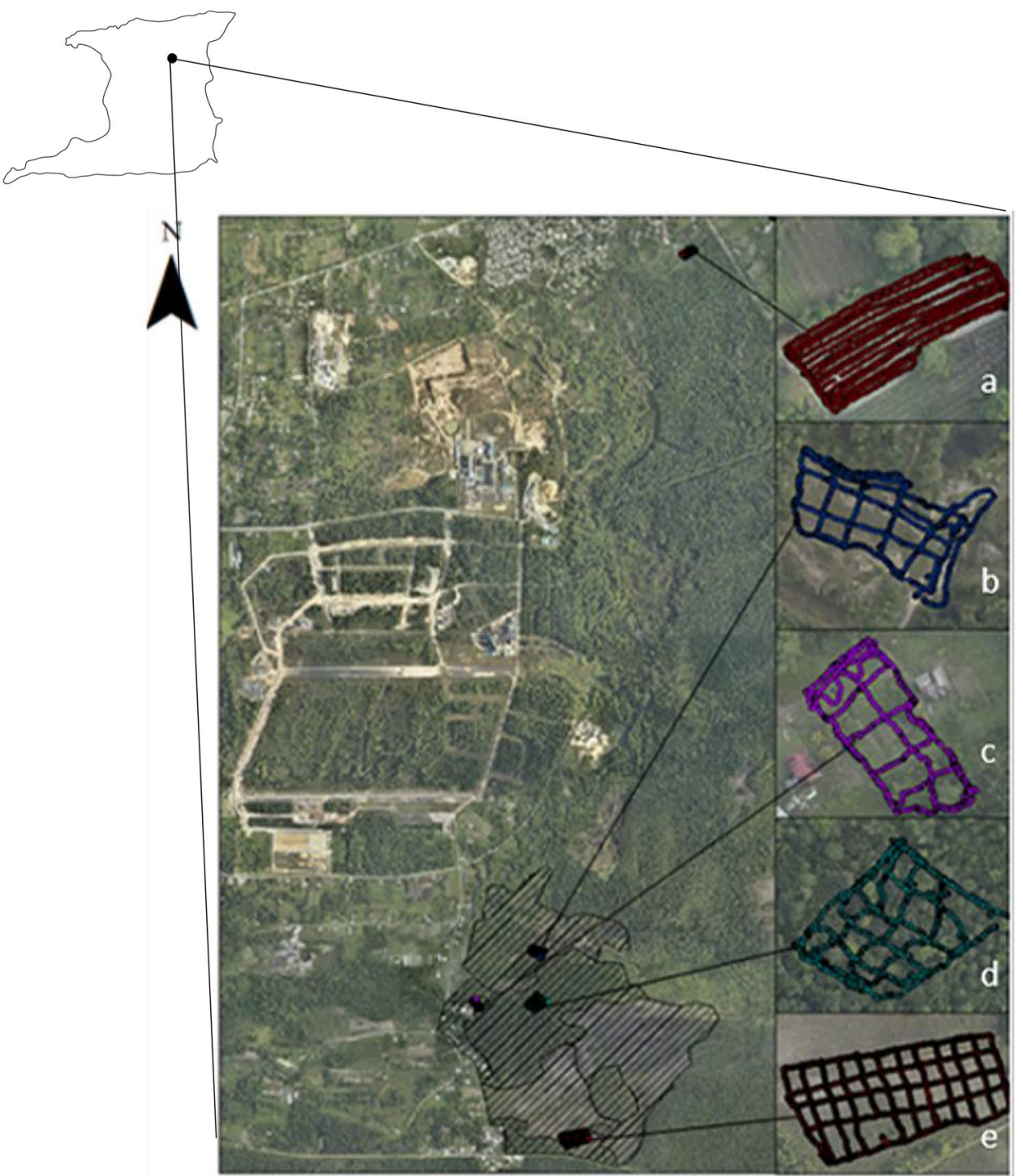

$\begin{array}{llll}0 & 0.275 & 0.55 & 1.1 \text { Kilometers }\end{array}$

Table 1 Site characteristics of study plots

\begin{tabular}{|c|c|c|c|c|}
\hline $\begin{array}{l}\text { Site/current land } \\
\text { use/land cover }\end{array}$ & Vegetation & Soil series & Parent material & Land use history \\
\hline Residential & Forest, Crop & Guanapo (Dystric Eutrudepts) & Fine, loamy. Micaceous & Forest, Squatting, Subsistence agriculture \\
\hline Quarry & $\begin{array}{l}\text { Palm marsh, } \\
\text { Grass, Sedge }\end{array}$ & Piarco (Typic Kanhaplaquults) & Fine. Kaolinitic & Grassland, Quarry \\
\hline Agriculture & Crops, Forest & Valencia (Kandic Plinthaquults) & Fine, loamy. Siliceous & Forest \\
\hline Grassland & Grass, sedge, & Piarco (Typic Kanhaplaquults) & Fine. Kaolinitic & Grassland, Ecotourism \\
\hline Forest & Forest & Piarco (Typic Kanhaplaquults) & Fine. Kaolinitic & $\begin{array}{l}\text { Timber harvesting, Hunting, Ecotourism, } \\
\text { US military base }\end{array}$ \\
\hline
\end{tabular}

This magnetic field induces currents in the earth which generate a secondary magnetic field. The ratio of both fields is assumed to be linearly proportional to the ground electrical conductivity [42].
The DUALEM-1S instrument was held parallel to the ground (approximately $0.2 \mathrm{~m}$ above the ground) using the vertical coil orientation. Measurements were made by navigating the field site in a predetermined grid-like

\section{SN Applied Sciences}


pattern. The grid-like EMI survey route was created by traversing the field site east-west and north-south at $\sim 10 \mathrm{~m}$ distances between the grid lines (Fig. 1). The surveyor without resting collects 2000 data points normally within an hour as the field computer is set to record every $2 \mathrm{~s}$. The EMI maps were then created by interpolating the data using kriging [48], following quality assurance/quality control procedures (such as the cleaning of data) and semivariograms. Changes in temperature have been known to influence the EMI signal [41] as such since the temperature was not constant throughout the surveys, temperature corrections were made for the soil ECa data prior to analysis using the following temperature correction equation [64]:

$\mathrm{EC}_{25}=\mathrm{EC}_{\mathrm{t}} \cdot f_{\mathrm{t}}$

where $\mathrm{EC}_{25}$ is the corrected electrical conductivity at the standard temperature of $25^{\circ} \mathrm{C}, \mathrm{EC}_{\mathrm{t}}$ is the electrical conductivity measured at ambient temperature and $f_{t}(0.925)$ is the correction factor at ambient temperature.

The EMI mapping of the five Aripo field sites were conducted between the hours of 9 am-12 noon at March 21st, April 23rd, May 28th and June 2nd of 2014 when the field was dry (daily rainfall/temp in March $21^{\text {st }}=0.4 \mathrm{~mm} / 28{ }^{\circ} \mathrm{C}$, April $23^{\text {rd }}=0.9 \mathrm{~mm} / 28{ }^{\circ} \mathrm{C}$, May $28 \mathrm{th}=0.6 \mathrm{~mm} / 29^{\circ} \mathrm{C}$, June $2 \mathrm{nd}=0.0 \mathrm{~mm} / 28^{\circ} \mathrm{C}$ ) indicating a very severe dry season compared with other years. The dominant vegetation type found are open areas of grass (Gramineae) and sedge (Cyperaceae) lying within a seasonal forest and palm marsh vegetation (Mauritia setigera Gr. \& Wendl).

\subsection{Soil properties measurements}

In addition to EMI measurements, the soil surface layer for the five study sites was measured using a Field Scout EC 110 m (Spectrum, Illinois) for electrical conductivity (EC) and temperature and a TDR 100 soil moisture meter (Spectrum, Illinois) for volumetric water content (VWC). A similar approach was used by De Benedetto et al. [18] who integrated data of different sensors to identify three homogeneous sub-field areas related to the intrinsic properties of soil. Measurements were made at geo-referenced locations in the Aripo savanna and recorded using a global positioning system (GPS) receiver and a field computer. Measurements were conducted simultaneously with ECa surveys at $15 \mathrm{~cm}$ depth. Measurements were taken at grid intersections using a portable TDR 100 soil moisture meter (Spectrum Illinois) and an EC 100 m, Spectrum Illinois. Sites were tested for conductivity, temperature, and volumetric water content within the 5 land use/land covers.

\subsection{Soil sampling and analysis}

A directed sampling design based on soil ECa variability was employed to collect soil samples that were representative of the 5 different field sites. 20 sample locations were generated for each field site (Fig. 2) using the ESAP-RSSD [39] for optimal stochastic calibration. Additionally, ECa, EC (Field Scout), temperature and soil moisture were collected at each location prior to collecting soil samples. A gouge auger for disturbed samples and cylindrical cores $5 \mathrm{~cm}$ in diameter and $5 \mathrm{~cm}$ high for undisturbed samples was used to manually collect soil samples from depths of 0-30 cm (auger) and 0-5 cm (core) respectively. Duplicate disturbed samples were collected at each sample location for the 5 field sites and were immediately sealed in Ziploc plastic bags to prevent moisture loss. Soil disturbance was evident within the $0-30 \mathrm{~cm}$ layers of the agriculture land cover.

The soil samples were transported back to the laboratory, disturbed subsamples and cores were promptly weighed (fresh mass) and analyzed for soil water content and bulk density by recording the dry mass after oven drying at $105^{\circ} \mathrm{C}$ to constant weight. The remaining samples were air dried, crushed and passed through a $2 \mathrm{~mm}$ sieve for soil physical and chemical analyses. Particle size analysis was performed using the hydrometer method [29] without prior removal of organic matter and Fe-Oxides. Preliminary investigation confirmed the findings of Ahmad and Roblins [5] and Wuddivira and Camps-Roach [70] that the binding effects of organic matter and free Fe-Oxides were negligible due to their inherently low concentrations in these soils. Soil solution electrical conductivity (ECe), $\mathrm{pH}$ and redox potential were measured from a saturated soil-water paste extract [50]. A loss on ignition method using a muffled furnace was used to determine the total organic carbon content in the soil samples [45].

\subsection{Data analysis}

\subsubsection{Geostatistical analysis}

D'Or et al. [21] described geostatistics as a well-established scientific discipline that provides flexible spatial analysis methods to accurately delineate areas. Normal score transformation of non-normal ECa data was performed [31]. Semi-variogram model parameters (sill, nugget, range) were determined for the ECa surveys in each of the five land uses to determine the correlation structure that underlies the spatial prediction for the kriging of these values. The sill can be described as the level at which the variogram flattens out, the nugget relates to the unexplained variance between pairs of points separated by very small distances, such as the measurement error and the range is 
Fig. 2 Soil sample locations in 5 different land uses in the Aripo savanna
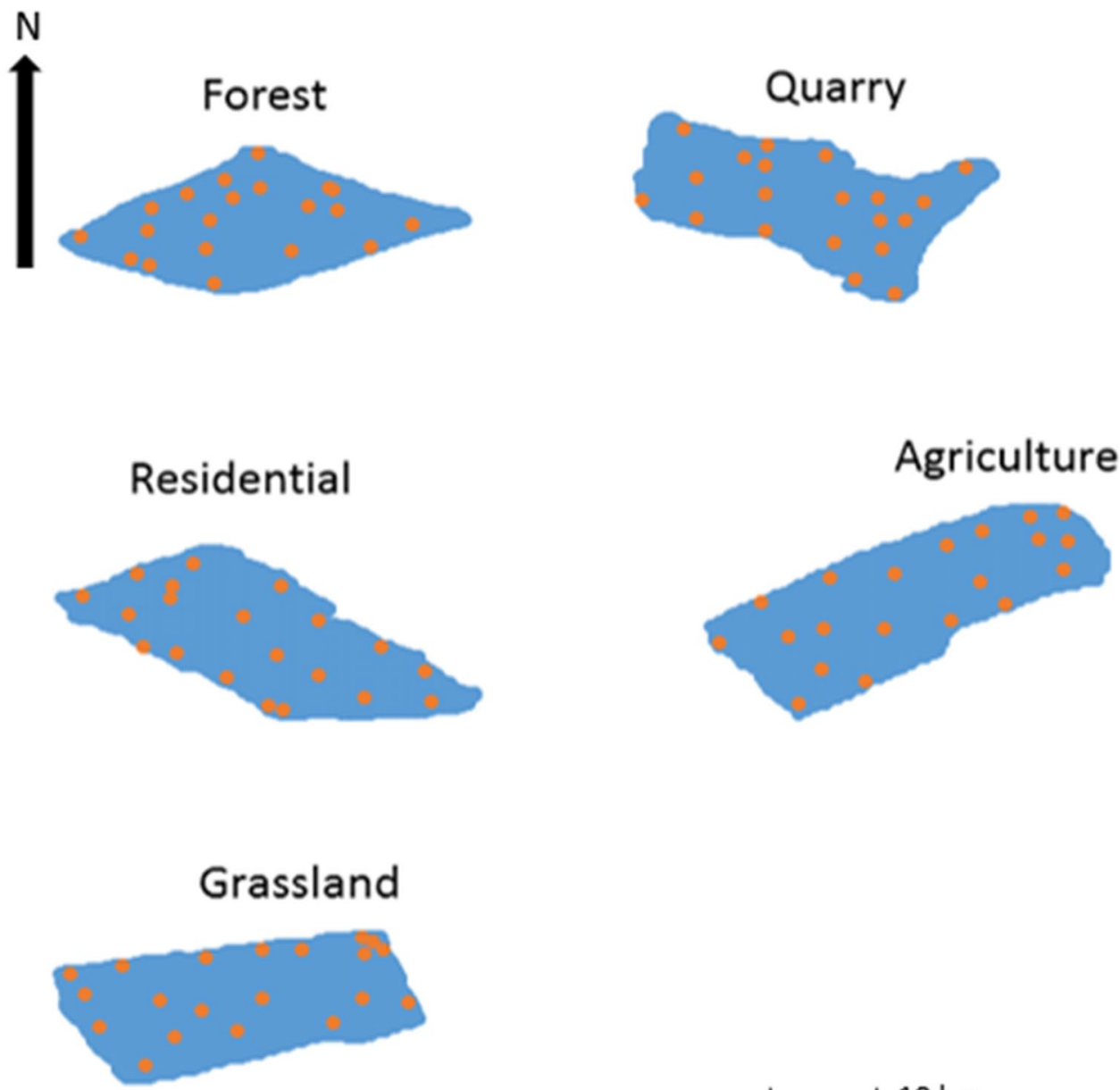

a measure of the spatial continuity of the variable of interest [67]. Simple kriging was used in the Gaussian method; kriging parameters include: interpolation grid spacing $10 \mathrm{~m}$, search ellipsoid $75 \mathrm{~m}$, azimuth, dip and rake were all set to 0 as 3D kriging was not needed. After kriging, the normal score transformed, interpolated data was backtransformed to the original distribution to improve reliability in the delineation of soil properties. The EMI values obtained were then paired with soil data using a nearest neighbour analysis in a spreadsheet [55]. This represented the closest linear distance from each soil sample location to the nearest kriged ECa data point. Transformations, semi-variograms and simple kriging were calculated using Stanford Geostatistical Modeling Software (SGEMS version $2.1 ;$ [48]) procedure outlined in Robinson et al. [54].

\subsubsection{Statistical analysis}

Summary statistics (Table 2) were obtained for the dataset, and the Shapiro-Wilk test was used to test the normality of the data for each soil parameter within land uses. All of the soil parameters were found to be normally distributed within the five field sites. Apparent electrical conductivity for the residential field site, however, had to be logarithmically transformed before application of statistical techniques and parametric analysis such as regression and Pearson correlation as heavy disturbance was evident yielding non-normal distribution. Soil quality factor score coefficients of soil samples were computed using principal component analysis (Table 3). Analysis of variance was used to discriminate the differences of the soil quality factor scores in different land use types.

\section{Results and discussion}

\subsection{Statistics of edaphic factors as a function of land use/land cover}

Variance in soil attributes can depend on several factors including land use. In this study land use was varied and soil attributes were used as a relative measure of land use sensitivity. Coefficient of variation (CV) within land uses was used to determine sensitivity to group soil variables as a function of land use (Table 2). Since climatic factors and topography (relatively flat) were assumed to be constant 
Table 2 Summary statistics of soil properties in the Aripo savanna, Trinidad

\begin{tabular}{|c|c|c|c|c|c|c|c|c|}
\hline Land use & $\begin{array}{l}\text { Bulk density } \\
\left(\mathrm{g} / \mathrm{cm}^{3}\right)\end{array}$ & VWC $\left(\mathrm{cm}^{3} / \mathrm{cm}^{3}\right)$ & Silt (\%) & Clay (\%) & SOC (\%) & $\mathrm{pH}$ & ${ }^{\dagger} \mathrm{EC}(\mu \mathrm{S} / \mathrm{cm})$ & $\operatorname{TEMP}\left({ }^{\circ} \mathrm{C}\right)$ \\
\hline \multicolumn{9}{|l|}{ Residential } \\
\hline Mean & $1.2^{c}$ & $0.4^{\mathrm{a}}$ & $28.8^{\mathrm{a}}$ & $12.3^{b c}$ & $2.2^{\mathrm{ab}}$ & $4.9^{\mathrm{ab}}$ & $146.3^{b}$ & $21.6^{\mathrm{cd}}$ \\
\hline Median & 1.3 & 0.4 & 27.5 & 12.1 & 2.0 & 4.8 & 130.4 & 21.7 \\
\hline Standard Deviation & 0.2 & 0.1 & 16.8 & 6.0 & 1.0 & 0.4 & 48.2 & 0.3 \\
\hline CV (\%) & 13.9 & 27.2 & 58.3 & 48.8 & 46.9 & 8.0 & 33.0 & 1.2 \\
\hline Maximum & 1.5 & 0.6 & 51.3 & 25.5 & 5.2 & 6.2 & 274.5 & 22.5 \\
\hline Minimum & 0.8 & 0.1 & 0.0 & 0.0 & 0.9 & 4.4 & 98.6 & 20.8 \\
\hline \multicolumn{9}{|l|}{ Quarry } \\
\hline Mean & $1.5^{\mathrm{a}}$ & $0.3^{b c}$ & $37.0^{\mathrm{a}}$ & $20.6^{a b}$ & $1.5^{b}$ & $4.9^{\mathrm{ab}}$ & $102.5^{\mathrm{b}}$ & $21.5^{d}$ \\
\hline Median & 1.5 & 0.3 & 41.8 & 23.3 & 1.6 & 4.9 & 98.2 & 21.5 \\
\hline Standard Deviation & 0.1 & 0.0 & 15.0 & 16.9 & 0.5 & 0.1 & 25.9 & 0.2 \\
\hline CV (\%) & 5.7 & 14.4 & 40.6 & 81.6 & 35.4 & 2.6 & 25.2 & 1.0 \\
\hline Maximum & 1.7 & 0.2 & 52.3 & 57.3 & 2.5 & 5.1 & 189.0 & 22.2 \\
\hline Minimum & 1.3 & 0.3 & 0.0 & 0.0 & 0.6 & 4.7 & 69.6 & 21.1 \\
\hline \multicolumn{9}{|l|}{ Agric. } \\
\hline Mean & $1.4^{\mathrm{ab}}$ & $0.3 b^{c}$ & $29.8^{\mathrm{a}}$ & $20.4^{\mathrm{ab}}$ & $1.5^{\mathrm{b}}$ & $5.0^{\mathrm{a}}$ & $218.5^{\mathrm{a}}$ & $22.1^{\mathrm{bc}}$ \\
\hline Median & 1.5 & 0.3 & 29.8 & 17.3 & 1.3 & 5.0 & 169.0 & 22.1 \\
\hline Standard Deviation & 0.1 & 0.0 & 13.8 & 9.9 & 0.6 & 0.2 & 157.8 & 0.3 \\
\hline CV (\%) & 6.5 & 16.0 & 46.4 & 48.4 & 43.0 & 4.8 & 72.2 & 1.5 \\
\hline Maximum & 1.6 & 0.3 & 65.5 & 44.6 & 3.1 & 5.6 & 830.0 & 23.0 \\
\hline Minimum & 1.2 & 0.2 & 13.6 & 0.0 & 0.4 & 4.6 & 119.4 & 21.5 \\
\hline \multicolumn{9}{|l|}{ Grass } \\
\hline Mean & $1.3^{b}$ & $0.4^{\mathrm{a}}$ & $36.3^{\mathrm{a}}$ & $5.0^{c}$ & $1.5^{\mathrm{b}}$ & $4.7^{b}$ & $89.2^{\mathrm{b}}$ & $26.4^{\mathrm{a}}$ \\
\hline Median & 1.3 & 0.4 & 37.7 & 0.0 & 0.9 & 4.7 & 87.4 & 26.2 \\
\hline Standard Deviation & 0.1 & 0.0 & 13.0 & 11.9 & 1.4 & 0.2 & 11.9 & 1.3 \\
\hline CV (\%) & 8.2 & 6.7 & 35.9 & 240.2 & 89.9 & 5.0 & 13.3 & 4.8 \\
\hline Maximum & 1.5 & 0.5 & 54.8 & 42.8 & 5.3 & 5.4 & 118.8 & 29.5 \\
\hline Minimum & 1.1 & 0.3 & 5.4 & 0.0 & 0.5 & 4.2 & 75.4 & 24.7 \\
\hline \multicolumn{9}{|l|}{ Forest } \\
\hline Mean & $1.1^{d}$ & $0.3^{b}$ & $13.4^{\mathrm{b}}$ & $27.3^{\mathrm{a}}$ & $2.7^{\mathrm{a}}$ & $4.4^{c}$ & $148.2^{\mathrm{b}}$ & $22.2^{\mathrm{b}}$ \\
\hline Median & 1.1 & 0.3 & 5.8 & 25.8 & 2.6 & 4.4 & 137.7 & 22.4 \\
\hline Standard Deviation & 0.1 & 0.0 & 15.5 & 11.8 & 0.7 & 0.1 & 34.4 & 0.4 \\
\hline CV (\%) & 10.7 & 14.2 & 116.0 & 43.2 & 27.6 & 2.7 & 23.2 & 1.8 \\
\hline Maximum & 1.3 & 0.4 & 42.2 & 52.7 & 4.9 & 4.6 & 208.4 & 22.8 \\
\hline Minimum & 0.9 & 0.2 & 0.0 & 0.0 & 1.6 & 4.2 & 105.2 & 21.6 \\
\hline
\end{tabular}

SOC soil organic carbon; VWCvolumetric water content; TEMP temperature

${ }^{\dagger} E C$ electrical conductivity collected from Field Scout EC $110 \mathrm{~m}$

Means followed by the same letter are not significantly different at $P<0.05$

in the study site, the impact of land use was essentially the cause of variance in soil properties, hence $\mathrm{CV}$ is a reflection of land use sensitivity. Consequent to this, $\mathrm{Xu}$ et al. [73] classified the sensitivity of land use using CV as follows: $C V s>100 \%$ reflected high sensitivity to land use, CVs $100-40 \%$ reflected moderate sensitivity to land use, CVs $40-10 \%$ reflected low sensitivity to land use and CVs $<10 \%$ reflected no sensitivity to land use. Given that all other factors besides land use/land cover was kept constant during soil sampling, variances in soil properties were used as a measure of sensitivity to land use/land cover. In the residential site, silt $(C V=58.3 \%)$, clay $(C V=48.8 \%)$ and SOC $(\mathrm{CV}=46.9 \%)$ had the higher CVs of moderate sensitivity, temperature had the lowest CV (1.2\%) reflecting no sensitivity to land use/land cover in the Aripo savanna. Temperature exhibited no sensitivity overall amongst the 5 land use/land covers. The quarry site also reflected moderate sensitivity for silt $(C V=40.6 \%)$ and clay $(C V=81.6 \%)$. Soil 
Table 3 Analysis of variance of soil quality factor scores in different land uses in the Aripo Savanna

\begin{tabular}{lllllll}
\hline Soil variables & \multicolumn{7}{l}{ Soil quality factor scores in different land use types } \\
\cline { 2 - 6 } & Residential & Quarry & Forest & Agriculture & Grassland & ANOVA F \\
\hline Bulk density $\left(\mathrm{g} / \mathrm{cm}^{3}\right)$ & -0.846 & -0.974 & 0.941 & 0.995 & -0.569 & $13.821^{*}$ \\
Pore space & 0.00 & -0.00 & -0.00 & -0.00 & -0.00 & $18.000^{*}$ \\
VWC $\left(\mathrm{cm}^{3} / \mathrm{cm}^{3}\right)$ & 0.709 & 0.295 & -0.411 & -0.583 & -0.675 & $17.122^{*}$ \\
EC $\left(\mu \mathrm{S} / \mathrm{cm}^{3}\right)$ & 0.375 & 0.923 & 0.648 & -0.670 & 0.623 & $11.911^{*}$ \\
Temperature $\left({ }^{\circ} \mathrm{C}\right)$ & -0.859 & -0.598 & 0.894 & 0.718 & 0.536 & $12.998^{*}$ \\
Clay $(\%)$ & 1.003 & -0.509 & 0.577 & 0.429 & 0.373 & $12.287^{*}$ \\
Silt-clay $(\%)$ & 0.091 & -0.319 & -0.556 & -0.531 & -0.874 & $22.497^{*}$ \\
pH & 0.680 & 0.651 & -0.776 & -0.707 & 0.890 & $12.842^{*}$ \\
SOC $(\%)$ & 0.183 & -0.834 & 0.562 & 0.555 & 0.233 & $14.467^{*}$ \\
Sample numbers & 20 & 20 & 20 & 20 & 20 & \\
\hline
\end{tabular}

*Significant difference at P 0.01 level texture attributes were most affected by the residential and quarry land covers due to activities from the nearby squatter settlement and the recently abandoned quarrying facility causing a change in particle size due to breakdown of peds. Silt $(C V=46.4 \%)$ and clay $(C V=48.4 \%)$ continued to reflect moderate sensitivity in the agricultural site, however, electrical conductivity ( $C V=72.2 \%)$ had the highest CV. Electrical conductivity (Field Scout) reflected moderate variability, mostly as a result of the influence of fertilizer inputs into the soil, however, principal component analysis indicated that it was significantly different, generally soil texture was most affected amongst land use/land covers. The forest site, reflected a high CV for silt ( $C V=116.0 \%)$ reflecting high organic matter contribution to soil texture in the forest land use. Clay CV (43.2\%) which was moderate could have been as a result of the soil erosion processes which influence the particle size distribution in this natural land use. In the grass site, clay had the highest CV (240.2\%) which reflected the exposure of the grassland land cover to erosive processes due to sparse vegetation coverage in the savanna, this may have influenced texture. The process of erosion can selectively distribute particles based on their size, thus erosion can influence soil texture [73]. Soil organic carbon CV (89.9\%) was moderate in the grass site. Soil texture in the grassland site indicated the heterogeneous nature of the soils due to the presence of the clay pan layer which comes closest to the surface at this site.

Analysis of variance of soil quality factor scores in different land use types (Table 3 ) revealed that certain soil variables were more sensitive to land use/land cover change than others. All soil variables were significantly affected by land use/land cover type. These variables represent dynamic soil properties that can be used for assessing effects of land use/land cover change [73]. The finer soil fractions of silt and clay were most affected by land use/ land cover as indicated by their high $\mathrm{F}$ values. Soil electrical conductivity (Field scout) was least affected by land use/ land cover change. Even though soil electrical conductivity is a dynamic property other soil variables were more sensitive to the controls of land use/land cover change.

Correlations across land use/land cover types (Table 4) indicate similarities and differences in parent material. Soil texture revealed correlations in all land uses except forest. Largest correlation was observed for silt and clay in the Quarry site. Finer soil fractions on the quarry $(r=-0.79)$ and grass sites $(r=-0.51)$ indicate similarities in parent material in the Aripo savanna which contains fine, kaolinitic materials (Table 1). Soil organic carbon had correlations with soil variables in all land uses. SOC was strongly correlated with bulk density and porosity for the residential and grass sites (Table 4). Positive relationships were observed for SOC and EC in the natural sites of forest and grass. In the human influenced sites a direct relationship between the two variables were not as distinct. The human influenced residential and quarry sites, however, had positive relationships between SOC and VWC. Water content

Table 4 Correlation ( $r$ ) between soil properties in different land use/land cover in Aripo Savanna, Trinidad

\begin{tabular}{llllll}
\hline Correlation & \multicolumn{4}{l}{ Land use/land cover } \\
\cline { 2 - 6 } & Residential & Quarry & Forest & Agriculture & Grass \\
\hline BD versus SOC & -0.73 & NA & NA & NA & -0.62 \\
Clay versus SOC & NA & NA & NA & -0.45 & 0.65 \\
PS versus SOC & 0.73 & NA & NA & NA & 0.62 \\
VWC versus pH & 0.46 & 0.52 & NA & NA & NA \\
VWC versus SOC & 0.52 & 0.52 & NA & NA & NA \\
EC versus SOC & NA & NA & 0.72 & NA & 0.63 \\
Silt versus Clay & NA & -0.79 & NA & -0.46 & -0.51 \\
\hline
\end{tabular}

$B D$ bulk density; SOC soil organic carbon; VWC volumetric water content, $P S$ porosity, $E C$ electrical conductivity

$N A$ no correlation 
in human influenced sites tend to be more variable than natural sites. Even though VWC can vary on a daily basis due to climate, it depends on non-ephemeral soil properties such as clay and SOC which vary spatially. SOC has been reported as a factor that influences soil water content variation [36].

Generally, electrical conductivity as a function of land use/land cover in the Aripo savannas revealed that EC was higher for anthropogenic sites, for example, agriculture than for non-anthropogenic sites such as grass.

\subsection{Apparent electrical conductivity as a function of land use/land cover}

The summary statistics (Table 5) revealed higher mean apparent electrical conductivity (Dualem EC meter) shallow $\left(E C a_{s}\right)$ than apparent electrical conductivity deep $\left(E C a_{d}\right)$ values in the anthropogenic land covers of residential $\left(\mathrm{ECa}_{\mathrm{s}}=305.9, \mathrm{ECa}_{\mathrm{d}}=76.1 \mathrm{mS} / \mathrm{m}\right)$, quarry $\left(\mathrm{ECa}_{\mathrm{s}}=21.9\right.$, $\left.\mathrm{ECa}_{\mathrm{d}}=3.3 \mathrm{mS} / \mathrm{m}\right)$ and agriculture $\left(\mathrm{ECa}_{\mathrm{s}}=5.6, \mathrm{ECa}_{\mathrm{d}}=5.1\right.$ $\mathrm{mS} / \mathrm{m}$ ). The increased sample size of the $E C$ a values aided in the identification of outliers which improved the accuracy of the results. The $\mathrm{ECa}_{\mathrm{s}}$ values have been shown to increase with water content and ions retained in soil solution $[23,54,72]$ as a result of inputs at the soil surface. Forest site $\mathrm{ECa}_{\mathrm{s}}(16.8 \mathrm{mS} / \mathrm{m})$ and $\mathrm{ECa}_{\mathrm{d}}(16.5 \mathrm{mS} / \mathrm{m})$ had similar means. Contrariwise, the mean $\mathrm{ECa}_{\mathrm{d}}$ was higher than the mean $\mathrm{ECa}_{\mathrm{s}}$ for the natural grassland site $\left(\mathrm{ECa}_{\mathrm{d}}=219.6\right.$, $\left.\mathrm{ECa}_{\mathrm{s}}=99.4 \mathrm{mS} / \mathrm{m}\right)$. In our study the relationship between $\mathrm{ECa}_{\mathrm{s}}$ and $\mathrm{VWC}$ was linearly positive in the natural sites (as VWC increased, ECa also increased). In the human influenced sites, however, there was either a negative correlation or no correlation at all reflecting disruption in soil quality.

The forest site had the largest range of $\mathrm{ECa}_{\mathrm{s}}$ values $\left(\mathrm{ECa}_{\mathrm{s}}=9.4-45.1 \mathrm{mS} / \mathrm{m}\right)$ while agriculture had the largest range of $\mathrm{ECa}_{\mathrm{d}}(1.5-31.3 \mathrm{mS} / \mathrm{m})$ values. The $\mathrm{ECa}_{\mathrm{s}}$ values may be attributable to the higher clay and organic contents found in the forest site (Table 2). Soil tillage practices combined with fertilizer applications may explain $\mathrm{ECa}_{\mathrm{d}}$ values in the agriculture site as the soil ionization increases. The quarry had the lowest range of $\mathrm{ECa}_{\mathrm{d}}$ values (1.3-6.6 $\mathrm{mS} / \mathrm{m}$ while the grassland site had the lowest range of $\mathrm{ECa}_{\mathrm{s}}$ values $(94.4-103.1 \mathrm{mS} / \mathrm{m})$. The standard deviation for the five land uses of residential, quarry, forest, grass and agriculture, $\mathrm{ECa}_{\mathrm{s}}$ and $\mathrm{ECa}_{\mathrm{d}}$ (Range Std dev $\mathrm{ECa}_{\mathrm{s}}=2.6-8.1$; Range Std dev $\left.E C a_{d}=1.4-6.3\right)$ and for the coefficient of variation (Range CV ECa $\mathrm{Ea}_{\mathrm{s}}$ 2.6-124.0\%; Range CV $\mathrm{ECa}_{d}=1.8-123.9 \%$ ) were generally high (Table 5) indicating high spatial variability. Also the standard deviation and coefficient of variation generally decreased with depth indicating less ECa variability at deeper depths as it is not exposed to climate and anthropogenic disturbances.

$\mathrm{ECa}_{\mathrm{s}}$ was significantly higher $(\angle P=0.001)$ in the forest site than all other land uses due to the clay and humus content present in the topsoil. Agriculture site, however, had a significantly lower mean ECa $(<P=0.001)$ than the other 4 land uses. This differs with what was found by the soil probe (Field scout) indicating that there may have been some interference to the EMI sensor moving from an open area in the agricultural site to the perimeter bordered by tall, thick forest canopy. For $\mathrm{ECa}_{\mathrm{d}}$, the mean value at the quarry site was significantly lower $<P=0.001$ than the other land uses except for agriculture where forest canopy interference to the EMI sensor may have occurred, while the $\mathrm{ECa}_{\mathrm{d}}$ mean value at the grass land use was significantly higher $\angle P=0.001$ than all other land uses due to the presence of the clay pan.

The $\mathrm{ECa}_{\mathrm{d}}$ semivariogram models exhibited slightly higher nuggets, slightly lower sills and shorter ranges for all land use/land covers except for quarry land (Table 6). Duffera et al. [22] presented a classification of spatial structure as follows: the variable with nugget-to-sill ratio of $<25 \%$ was considered strongly spatially dependent; the ratio between 25 and $75 \%$, was considered moderately spatially dependent; and the ratio $>75 \%$ was considered weakly spatially dependent. This classification system was used to quantify the degree of spatial dependence based

Table 5 Summary statistics of apparent soil electrical conductivity shallow $\left(E C a_{s}\right)$ and deep $\left(E C a_{d}\right)$ in the different land use/land cover sites in the Aripo savanna, Trinidad

\begin{tabular}{|c|c|c|c|c|c|c|c|c|c|c|c|c|}
\hline \multirow[t]{2}{*}{ Land Use/land cover } & \multicolumn{6}{|c|}{${ }^{ \pm} \mathrm{ECa}_{\mathrm{s}}(\mathrm{mS} / \mathrm{m})$} & \multicolumn{6}{|c|}{$\mathrm{ECa}_{\mathrm{d}}(\mathrm{mS} / \mathrm{m})$} \\
\hline & Mean & Median & Min & Max & Std. Dev. & CV (\%) & Mean & Median & Min & Max & Std. Dev & CV (\%) \\
\hline Residential & $305.9^{\mathrm{a}}$ & 301.3 & 67.8 & 83.7 & 4.5 & 6.8 & $76.1^{\mathrm{a}}$ & 76.3 & 67.8 & 83.7 & 4.5 & 5.9 \\
\hline Quarry & $21.9^{b}$ & 20.4 & 15.4 & 29.1 & 5.3 & 24.2 & $3.3^{b}$ & 3.2 & 1.3 & 6.6 & 1.4 & 42.9 \\
\hline Agriculture & $5.6^{c}$ & 4.2 & 1.7 & 34.7 & 7.0 & 124.0 & $5.1^{\mathrm{bc}}$ & 3.8 & 1.5 & 31.3 & 6.3 & 123.8 \\
\hline Grass & $99.4^{d}$ & 99.7 & 94.4 & 103.1 & 2.6 & 2.6 & $219.6^{d}$ & 219.8 & 225.0 & 225.0 & 4.0 & 1.8 \\
\hline Forest & $16.8^{\mathrm{e}}$ & 13.6 & 9.4 & 45.3 & 8.1 & 48.2 & $16.5^{\mathrm{e}}$ & 14.9 & 11.8 & 38.4 & 5.5 & 33.2 \\
\hline
\end{tabular}

${ }^{ \pm}$ECa represents apparent electrical conductivity data collected by Dualem EC meter

Means followed by the same letter are not significantly different at $P<0.05$ 
Table 6 Semivariogram parameters for the analysis of spatial dependence as a function of land use/land cover in the Aripo savanna, Trinidad

\begin{tabular}{llllllll}
\hline Land use/land cover & Model & Nugget & Partial sill & Sill & $\begin{array}{l}\text { Relative } \\
\text { structure }\end{array}$ & $\begin{array}{l}\text { Nugget } \\
\text { semi-vari- } \\
\text { ance }\end{array}$ & Range \\
\hline ECa shallow & & & & & & & \\
Residential & Gaussian & 0.4 & 2 & 2.4 & 0.83 & 16 & 99 \\
Quarry & Spherical & 0.5 & 0.5 & 1 & 0.5 & 50 & 42 \\
Agriculture & Spherical & 0.5 & 0.7 & 1.2 & 0.58 & 42 & 66 \\
Grassland & Spherical & 0.4 & 0.69 & 1.09 & 0.63 & 36.7 & 81 \\
Forest & Spherical & 0.6 & 0.47 & 1.09 & 0.43 & 55 & 25 \\
ECa deep & & & & & & & \\
Residential & Exponential & 0.5 & 0.52 & 1.02 & 0.51 & 49 & 16 \\
Quarry & Exponential & 0.6 & 0.61 & 1.21 & 0.5 & 49.5 & 52 \\
Agriculture & Spherical & 0.7 & 0.35 & 1.05 & 0.33 & 66.7 & 25 \\
Grassland & Spherical & 0.7 & 0.26 & 0.96 & 0.27 & 72.9 & 63 \\
Forest & Spherical & 0.6 & 0.48 & 1.08 & 0.44 & 55.6 & 22 \\
\hline
\end{tabular}

ECa apparent electrical conductivity from Dualem 1S EC meter on the nugget semivariance expressed as a percentage of the total semivariance (nugget to sill ratio). Due to the different meanings of semivariogram model parameters for different model types, the nugget-sill ratio can only be compared for the same model type and not across different model types. Strong spatial dependence was observed for $\mathrm{ECa}_{\mathrm{s}}$ (nugget semivariance $=16 \%$ ) in the residential lands suggesting that the Gaussian fitted model had a greater accuracy in prediction. All other models (both exponential and spherical), exhibited a moderate spatial dependence (nugget semivariance range: Quarry $=50 \%$, Forest $=55 \%$, Grass $=36.7 \%$, Agriculture $=42 \%$ ) suggesting less accuracy in prediction but exhibiting spatial structure and correlation (Table 6). Both spherical and Gaussian models were fitted to $\mathrm{ECa}_{\mathrm{s}}$ and spherical and exponential models to $\mathrm{ECa}_{\mathrm{d}}$. Spherical models were fitted where ECa sample points had a linear behaviour in origin and had a higher level of short range variability [12], these can be observed in forest, grassland and agriculture land use/land covers as well as Quarry $\mathrm{ECa}_{\mathrm{s}}$. A Gaussian model was fitted to the residential site $\mathrm{ECa}_{\mathrm{s}}$ as it exhibited a continuous gradually varying structure [46]. Residential and quarry $\mathrm{ECa}_{\mathrm{d}}$ sites were fitted with an exponential model as abrupt changes over distances can be observed in the soil property.

The kriged spatial ECa $\mathrm{E}_{\mathrm{s}}$ and $\mathrm{ECa}_{\mathrm{d}}$ maps for the five different land use/land covers are displayed in Fig. 3. Kriged maps generally revealed more variability at the shallow depths $(0-0.5 \mathrm{~m})$ than the deeper depths $(0-1.5 \mathrm{~m})$ for each land use (Fig. 3). This is consistent with the existence of high variability in raw data at plot scales. This effect is highlighted by the fact that sample volumes typically used to measure plot scale variability are sensitive to the effect of small areas of high- or low variance as compared to larger sample volumes on a landscape scale. Generally, the anthropogenic sites of residential, quarry and agriculture, however, had a greater range in $\mathrm{ECa}\left(\mathrm{ECa}_{\mathrm{s}}\right.$ and $\left.\mathrm{ECa}_{\mathrm{d}}\right)$ values than the natural land use/land covers of forests and grasslands. Greater ECa ranges were obtained as expected, as evidence of greater spatial variability from domestic, agricultural inputs and mining. In addition to these activities, the accumulation of water due to the poor drainage of soils increased ECa values [15].

The residential site kriged $\mathrm{ECa}_{\mathrm{s}}$ values were greater than kriged $\mathrm{ECa}_{\mathrm{d}}$ values $\left(\mathrm{ECa}_{\mathrm{s}}\right.$ range $\left.=39.2-60.0 \mathrm{mS} / \mathrm{m}\right)$. Lowest kriged $\mathrm{ECa}_{\mathrm{s}}$ values were located on the southern region of the residential field site; this gradually gave way to higher values towards the northern and western regions of the residential field site. Generally, a similar spatial pattern was observed in the kriged $\mathrm{ECa}_{\mathrm{d}}$ property with increased scattered high value points due to buried refuse strewn across the site. For quarry, kriged $\mathrm{ECa}_{\mathrm{s}}$ values were higher ranging between 22.8 and $30.5 \mathrm{mS} / \mathrm{m}$ while kriged $\mathrm{ECa}_{\mathrm{d}}$ values were lower $\left(\mathrm{ECa}_{\mathrm{d}}\right.$ range $\left.=3.6-5.3 \mathrm{mS} / \mathrm{m}\right)$. The observed spatial distribution of kriged $\mathrm{ECa}_{\mathrm{s}}$ had the lowest values in the north-east except for the high electrical conductive values in the north-eastern most edge, the eastern margin and the south-eastern regions of the quarry field site. The highest values were observed in scattered clumps in the southern, central and north-western area of the quarry. The spatial distribution for the kriged $\mathrm{ECa}_{\mathrm{d}}$, however, had the lowest values generally in the north-east, west and southern regions of the quarry (Fig. 3). Water bodies were observed surrounding the quarry site at these particular locales and maybe responsible for the $\mathrm{ECa}_{\mathrm{d}}$ values obtained. In the forest, kriged $\mathrm{ECa}_{\mathrm{s}}$ ranges were lower $\left(\mathrm{ECa}_{\mathrm{s}}\right.$ range $=9.3-14.5 \mathrm{mS} / \mathrm{m})$ than kriged $\mathrm{ECa}_{\mathrm{d}}$ ranges $\left(\mathrm{ECa}_{\mathrm{d}}\right.$ range $=22.7-23.9 \mathrm{mS} / \mathrm{m}$ ). The pattern of kriged $\mathrm{ECa}_{\mathrm{s}}$ distribution revealed lowest values on the north-western region of the forest site, gradually increasing in value towards 

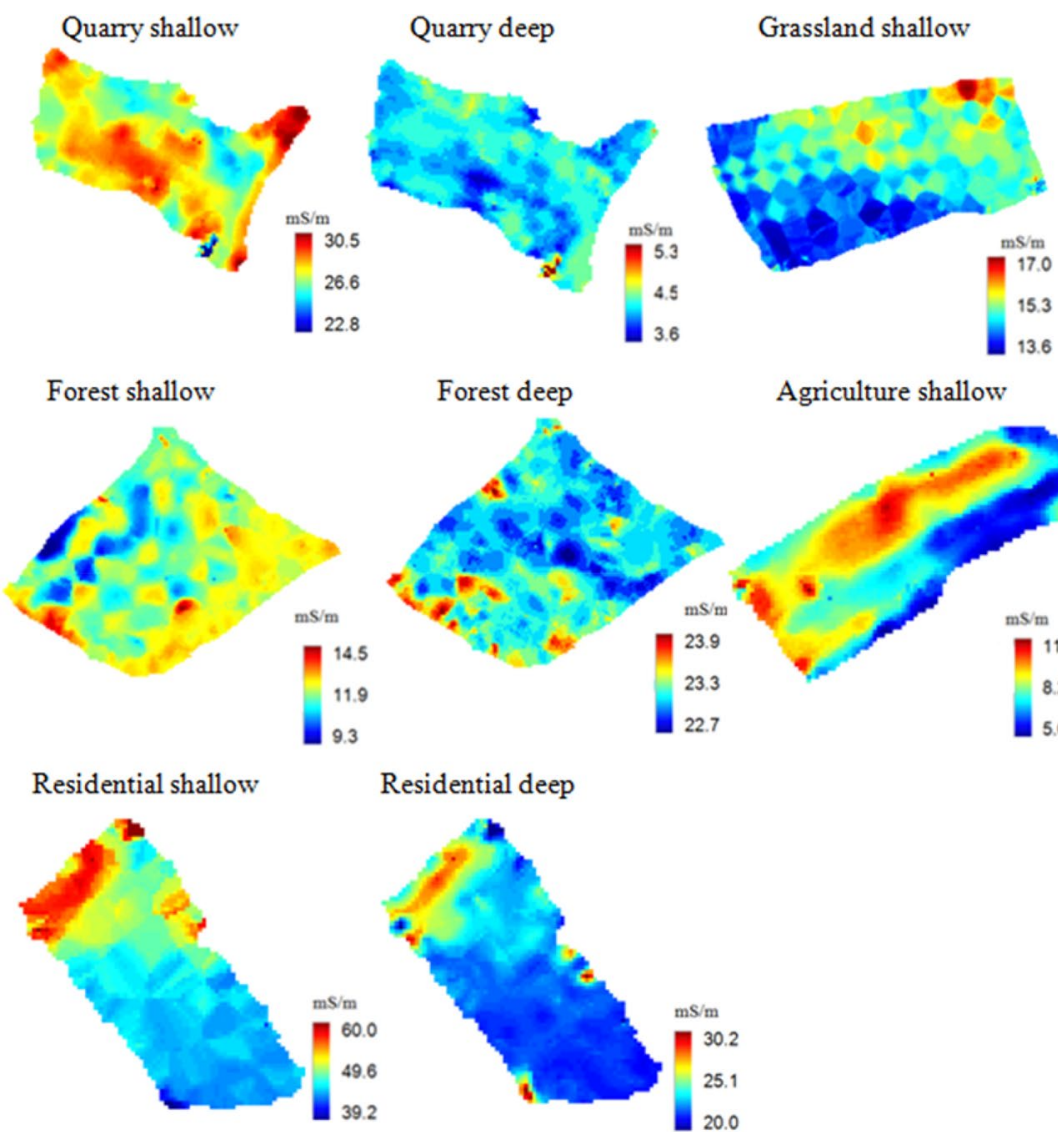

Agriculture shallow

Residential deep

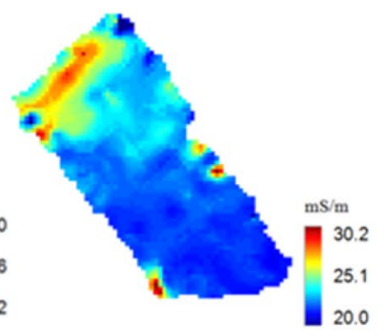

Grassland deep

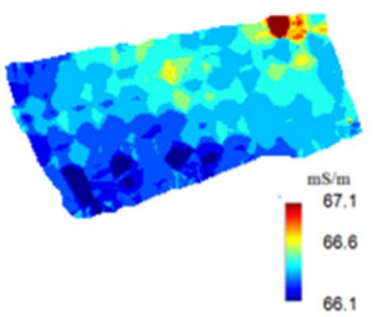

Agriculture deep

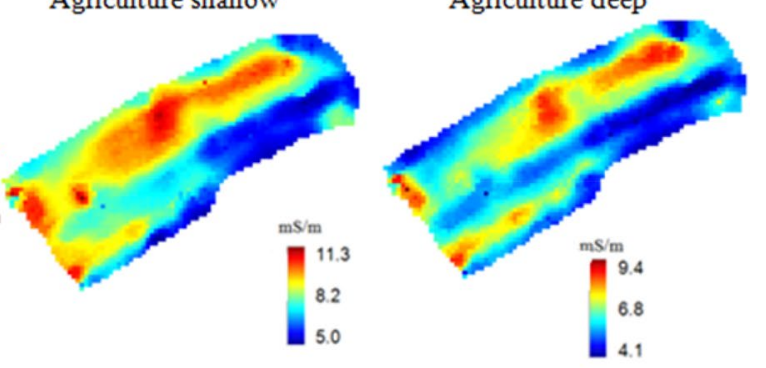

Fig. 3 Kriged apparent electrical conductivity (ECa) shallow and deep spatial maps for each land use

the southern and south-eastern regions. Kriged $\mathrm{ECa}_{\mathrm{d}}$ lowest values were distributed in the northern, eastern and central regions of the forest, again giving way to gradually increasing values towards the south-western region where a river boarded the site and may have contributed to higher water content. For grassland site, the kriged $\mathrm{ECa}_{\mathrm{s}}$ values were lower than the kriged $\mathrm{ECa}_{\mathrm{d}}$ values $\left(\mathrm{ECa}_{\mathrm{s}}\right.$ range $=13.6-17.0 \mathrm{mS} / \mathrm{m}, \mathrm{ECa}_{\mathrm{d}}$ range $=66.1-67.1 \mathrm{mS} / \mathrm{m}$ ). The spatial distribution of kriged $\mathrm{ECa}_{\mathrm{s}}$ had the lowest values in the south-western region of the grassland, giving way to a gradual increase in kriged $\mathrm{ECa}_{\mathrm{s}}$ values towards the north-eastern region. Kriged $\mathrm{ECa}_{\mathrm{d}}$ spatial distribution exhibited a similar pattern (Fig. 3). Parent material differences across the grassland site may have contributed to the $\mathrm{ECa}_{\mathrm{s}}$ and $\mathrm{ECa}_{\mathrm{d}}$ values. For the agriculture site, kriged $\mathrm{ECa}_{\mathrm{s}}$ had higher ranges $\left(\mathrm{ECa}_{\mathrm{s}}=5.0-11.3 \mathrm{mS} / \mathrm{m}\right)$ than kriged $E C a_{d}\left(E C a_{d}\right.$ range $\left.=4.1-9.4 \mathrm{mS} / \mathrm{m}\right)$. Spatial distribution of kriged $E C a_{s}$ values revealed lowest values in the north and east regions which generally increased to the south and west region of the agriculture field site. Similar patterns were observed for kriged $\mathrm{ECa}_{\mathrm{d}}$ indicating that agriculture practices over a lengthy period influences both shallow and deeper layers in the soil.

\section{3 $\mathrm{ECa}_{\mathrm{s}}$ signal relationship with soil properties in the Aripo Savanna}

EMI-based ECa measurements is a proxy for inferring dominant soil properties at the field scales [35]. EMI as a proxy for inferring soil properties was also reported by Atwell et al. [7] who calibrated ECa surveys to the electrical conductivity of saturation extract within a tropical wetland. Taylor et al. [61] also investigated electromagnetic induction as a surrogate for detailed soil coring.

Pearson correlations between soil properties and the $\mathrm{ECa}_{\mathrm{s}}$ signal within three of the five land use/land covers (Table 7), showed that VWC $(r=0.49, P=0.030)$ and silt $(r=0.49, P=0.03)$ in the forest land cover, were significantly correlated with the $\mathrm{ECa}_{\mathrm{s}}$ signal. This indicates that $\mathrm{ECa}_{\mathrm{s}}$ was primarily controlled by water content and soil texture within the forest. Within the grassland cover soil texture (clay) and water content also had a significant correlation with the $\mathrm{ECa}_{\mathrm{s}}$ signal suggesting that the bulk soil electrical conductivity response was also primarily controlled by soil texture (clay) and water content in this particular land cover (Table 7). Flow of electrical conductivity through materials such as soil are explained by models developed 
Table 7 Correlation between $\mathrm{ECa}_{\mathrm{s}}$ signal and soil properties in different land use/land cover Sites in the Aripo savanna, Trinidad

\begin{tabular}{lcccc}
\hline Land use/land cover & \multicolumn{4}{l}{$\begin{array}{l}\text { Correlation coefficient }(r) \text { with } P \text { values in } \\
\text { parenthesis }\end{array}$} \\
\cline { 2 - 5 } & Silt+Clay & VWC & Silt & $\mathrm{pH}$ \\
\hline Residential & -0.055 & 0.293 & -0.012 & 0.235 \\
& $(0.817)$ & $(0.209)$ & $(0.959)$ & $(0.319)$ \\
Quarry & -0.089 & -0.010 & -0.028 & -0.253 \\
& $(0.710)$ & $(0.968)$ & $(0.906)$ & $(0.281)$ \\
Agriculture & -0.335 & $-\mathbf{0 . 5 4 9}$ & -0.122 & $\mathbf{0 . 5 9 2}$ \\
& $(0.148)$ & $\mathbf{( 0 . 0 1 2 )}$ & $(0.608)$ & $\mathbf{( 0 . 0 0 6 )}$ \\
Grass & $\mathbf{0 . 5 6 0}$ & $\mathbf{0 . 6 5 3}$ & $-\mathbf{0 . 4 9 5}$ & 0.132 \\
& $\mathbf{( 0 . 0 1 0 )}$ & $(\mathbf{0 . 7 8 6 )}$ & $\mathbf{0 . 0 2 6}$ & $(0.579)$ \\
Forest & 0.380 & $\mathbf{0 . 4 8 6}$ & $\mathbf{0 . 4 8 6}$ & 0.122 \\
& $(0.098)$ & $\mathbf{( 0 . 0 3 0 )}$ & $\mathbf{( 0 . 0 3 0 )}$ & $(0.607)$ \\
\hline
\end{tabular}

Correlation coefficients in bold are significant at $P<0.05$

by Archie [6], Mc Neill [42] and Ruffet et al. [57]. In the agricultural land cover, water content $(r=-0.55, P=0.01)$ and $\mathrm{pH}(\mathrm{r}=0.59, P=0.01)$ had significant negative and positive correlations, respectively with $\mathrm{ECa}_{\mathrm{s}}$. This maybe a result of irrigation practices on the agricultural site disrupting natural water gradients resulting in soil mineralization of organic matter within the soil. Bulk soil electrical conductivity provides valuable information on the nutrient content and acidity of the soil. This is critical to site specific management of agricultural inputs $[2,20]$.

\section{Conclusion}

Our study shows that there were spatial variations in apparent electrical conductivity at both shallow $(0-0.5 \mathrm{~m})$ and deep (0-1.5 m) depths. Shallower depths, however, exhibited larger spatial variations due to the effects of different anthropogenic land uses/land covers and changes in the transient properties of water content and temperature.

Relationships between apparent electrical conductivity and soil properties indicate that soil properties such as VWC $(r=0.49)$ and silt $(r=0.49)$ were associated with the EMI signal in the forest land use, while VWC $(r=-0.549$ and $\mathrm{pH}(\mathrm{r}=0.592)$ soil properties, were associated with the signal in the agriculture field site. Within the grass land use, soil texture (clay) as a result of the clay pan influencing edaphic properties was mostly correlated with the EMI signal. Soil texture, however, reflected the impacts of erosive processes and organic matter content to land use in the natural sites and sensitivity in the anthropogenic sites. Soil texture dominance in the natural sites indicates that in tropical soils that are predominantly light textured (clay content $<21 \%$ ), silt content controls the EMI signal which can become of low influence following disturbance.

Acknowledgements This study was funded by the University of the West Indies, St. Augustine Campus through the Campus Research and Publication Fund grant no. CRP.3.MAR15.15.

Funding This study was funded by The University of the West Indies (CRP.3.MAR15.15).

\section{Compliance with ethical standards}

Conflict of interest The authors declare that they have no conflict of interest.

\section{References}

1. Abdu H, Robinson DA, Jones SB (2007) Comparing bulk soil electrical conductivity determination using the DUALEM-1S and EM38-DD electromagnetic induction instruments. Soil Sci Soc Am J 1:189-196

2. Adamchuk VI, Hummel JW, Morgan MT, Upadhyaya SK (2004) On-the-go soil sensors for precision agriculture. Comput Electron Agric 1:71-91

3. Adejuwon JO, Ekanade O (1988) A comparison of soil properties under different landuse types in a part of the Nigerian cocoa belt. CATENA 3:319-331

4. Ahmad N, Jones RL (1969) A plinthaquult of the Aripo Savannas, North Trinidad: I. Properties of the soil and chemical composition of the natural vegetation. Soil Sci Soc Am J 5:762-765

5. Ahmad N, Roblins AJ (1971) Crusting of River Estate soil, Trinidad, and its effect on gaseous diffusion, percolation, and seedling emergence. J Soil Sci 22:23-31

6. Archie GE (1942) The electrical resistivity log as an aid in determining some reservoir characteristics. Trans Am Inst Min Metall Pet Eng 146:54-62

7. Atwell M, Wuddivira MN, Gobin J, Robinson DA (2013) Edaphic controls on sedge invasion in a tropical wetland assessed with electromagnetic induction. Soil Sci Soc Am J 5:1865-1874

8. Atwell MA, Wuddivira MN, De Caires SA (2014) Seasonal effects on the correlation between electromagnetic-induction signals and the properties of two Trinidad soils. Trop Agric 91:187-196

9. Atwell MA, Wuddivira MN, Wilson M (2018) Sustainable management of tropical small island ecosystems for the optimization of soil natural capital and ecosystem services: a case of a Caribbean soil ecosystem-Aripo savannas Trinidad. J Soils Sedim 18(4):1654-1667

10. Blöschl G, Grayson R (2000) Spatial observations and interpolation. In: Grayson R, Blöschl G (eds) Spatial patterns in hydrology: Observations and modelling. Cambridge University Press, Cambridge, pp 17-50

11. Bréchet $L$, Oatham $M$, Wuddivira $M$, Robinson DA (2012) Determining spatial variation in soil properties in teak and native tropical forest plots using electromagnetic induction. Vadose Zone J. https://doi.org/10.2136/vzj2011.0102

12. Bohling $G$ (2005) Introduction to geostatistics and variogram analysis. Kansas Geol Surv 1:1-20

13. Bormann H, Klaassen $\mathrm{K}$ (2008) Seasonal and land use dependent variability of soil hydraulic and soil hydrological properties of two Northern German soils. Geoderma 3:295-302

14. Burgos P, Madejón E, Pérez-de-Mora A, Cabrera F (2006) Spatial variability of the chemical characteristics of a 
trace-element-contaminated soil before and after remediation. Geoderma 1:157-175

15. Corwin DL, Lesch SM (2005) Apparent soil electrical conductivity measurements in agriculture. Comput Electron Agric 46(13):11-43. https://doi.org/10.1016/j.compag.2004.10.005

16. Dalton FN, Herkelrath WN, Rawlins DS, Rhoades JD (1984) Time domain reflectometry: simultaneous measurement of soil water content and electrical conductivity with a single probe. Science 224:989-990

17. Dasberg S, Dalton FN (1985) Time domain reflectometry field measurements of soil water content and electrical conductivity. Soil Sci Soc Am J 2:293-297

18. De Benedetto D, Castrignano A, Diacono M, Rinaldi M, Ruggieri S, Tamborrino R (2013) Field partition by proximal and remote sensing data fusion. Biosyst Eng 4:372-383

19. De Caires SA, Wuddivira MN, Bekele I (2014) Assessing the temporal stability of spatial patterns of soil apparent electrical conductivity using geophysical methods. Int Agrophys 28:423-433

20. De Caires SA, Wuddivira MN, Bekele I (2015) Spatial analysis for management zone delineation in a humid tropic cocoa plantation. Prec Agric 16:129-147

21. D'Or D, Demougeot-Renard H, Garcia M (2009) An integrated geostatistical approach for contaminated site and soil characterisation. Math Geosci 41:307-322

22. Duffera M, White JG, Weisz R (2007) Spatial variability of Southeastern US Coastal Plain soil physical properties: implications for site-specific management. Geoderma 3:327-339

23. Ekwue El, Bartholomew J (2011) Electrical conductivity of some soils in Trinidad as affected by density, water and peat content. Biosyst Eng 2:95-103

24. Environmental Management Authority (EMA) (2007) Aripo savannas environmentally sensitive area literature review to facilitate the preparation of management plans. Prepared by the Caribbean Natural Resources Institute (CANARI), Port of Spain, Trinidad

25. Fahnestock P, Lal R, Hall GF (1996) Land use and erosional effects on two Ohio Alfisols: I. Soil properties. J Sustain Agric 2-3:63-84

26. Fitzjohn C, Ternan JL, Williams AG, Perez-Gonzalez A, De Alba S (2002) Dealing with soil variability: some insights from land degradation research in central Spain. Land Degrad Dev J 2:141-150

27. Friedman SP (2005) Soil properties influencing apparent electrical conductivity: a review. Comput Electron Agric 46(1-3):45-70

28. Gao P, Collins L, Garber PM, Geng N, Carin L (2000) Classification of landmine-like metal targets using wideband electromagnetic induction. IEEE Trans Geosci Remote Sens 3:1352-1361

29. Gee GW, Bauder JW (1986) Particle-size analysis. In: Klute A (ed) Methods of soil analysis. Part 1-Physical and mineralogical methods. SSSA Book Ser. 5.1. SSSA, ASA, Madison, pp 383-411. https://doi.org/10.2136/sssabookser5.1.2ed.c15

30. Godwin RJ, Miller PCH (2003) A review of the technologies for mapping within-field variability. Biosyst Eng 4:393-407

31. Goovaerts P (1997) Geostatistics for natural resources evaluation. Oxford University Press, Oxford

32. Guo LB, Gifford RM (2002) Soil carbon stocks and land use change: a meta-analysis. Glob Change Biol 4:345-360

33. Haas C, Gerland S, Eicken H, Miller H (1997) Comparison of seaice thickness measurements under summer and winter conditions in the Arctic using a small electromagnetic induction device. Geophysics 3:749-757

34. Haimelin R (2008) Mapping soil water content on agricultural fields using electromagnetic induction. Report. Helsinki Univ. of Technol., Helsinki, Finland, p 65

35. Hendrickx JMH, Kachanoski RG (2002) Nonintrusive electromagnetic induction. In: Dane JH, Topp GC (eds) Methods of soil analysis. Part 4, Physical methods. SSSA Book Ser. 5. SSSA. SSSA, Madison, pp 1297-1306
36. Hudson BD (1994) Soil organic matter and available water capacity. J Soil Water Conserv 49(2):189-194

37. Kachanoski RG, Wesenbeeck IV, Gregorich E (1988) Estimating spatial variations of soil water content using noncontacting electromagnetic inductive methods. Can J Soil Sci 4:715-722

38. Lal R (2005) Soil erosion and carbon dynamics. Soil Till Res 2:137-142

39. Lesch SM, Rhoades JD, Corwin DL, Robinson DA, Suarez DL (2002): ESAP-RSSD version 2.30 R. User manual and tutorial guide. Research Report 148

40. Martinez G, Vanderlinden K, Ordonez R, Muriel JL (2009) Can apparent electrical conductivity improve the spatial characterization of soil organic carbon? Vadose Zone J 3:586-593. https:// doi.org/10.2136/vzj2008.0123

41. McKenzie RC, George RJ, Woods SA, Cannon ME, Bennett DL (1997) Use of the electromagnetic-induction meter (EM38) as a tool in managing salinisation. Hydrog J 1:37-50

42. McNeill JD (1980) Electromagnetic terrain conductivity measurement at low induction numbers. Technical Note TN-6. Geonics, ON, Canada. http://www.geonics.com/html/technicalnotes.html (verified 22 Jan 2008)

43. Moral FJ, Terrón JM, Da Silva JM (2010) Delineation of management zones using mobile measurements of soil apparent electrical conductivity and multivariate geostatistical techniques. Soil Tillage Res 106(2):335-343

44. Naderi-Boldaji M, Sharifi A, Hemmat A, Alimardani R, Keller T (2014) Feasibility study on the potential of electrical conductivity sensor Veris 3100 for field mapping of topsoil strength. Biosyst Eng 126:1-11

45. Nelson DW, Sommers LE (1996) Total carbon, organic carbon, and organic matter. In: Bigham JM et al (ed) Methods of soil analysis. Part 3. Chemical methods-SSSA book series no. 5. Soil Science Society of America and American Society of Agronomy, Madison, WI, Chapter 34, pp 1001-1006

46. Ogunwole JO, Obidike EO, Timm LC, Odunze AC, Gabriels DM (2014) Assessment of spatial distribution of selected soil properties using geospatial statistical tools. Commun Soil Sci Plant Anal 16:2182-2200

47. Reiners WA, Bouwman AF, Parsons WFJ, Keller M (1994) Tropical rain forest conversion to pasture: changes in vegetation and soil properties. J Appl Ecol 2:363-377

48. Remy N (2005) S-GeMS: the stanford geostatistical modeling software: a tool for new algorithms development. In: Geostatistics Banff 2004. Springer, Dordrecht, pp 865-871

49. Rhoades JD, Manteghi NA, Shouse PJ, Alves WJ (1989) Soil electrical conductivity and soil salinity: new formulations and calibrations. Soil Sci Soc Am J 2:433-439

50. Rhoades JD, Chanduvi F, Lesch SM (1999) Soil salinity assessment: methods and interpretation of electrical conductivity measurements, vol 2. Food \& Agriculture Organization of the UN (FAO), Rome

51. Rhoades JD, Ingvalson RD (1971) Determining salinity in field soils with soil resistance measurements. Soil Sci Soc Am Proc 35:54-60

52. Rhoades JD, van Schilfgaarde J (1976) An electrical conductivity probe for determining soil salinity. Soil Sci Soc Am J 40:647-650

53. Robinson DA, Jones SB, Wraith JM, Or D, Friedman SP (2003) A review of advances in dielectric and electrical conductivity measurement using time domain reflectometry: simultaneous measurement of water content and bulk electrical conductivity in soils and porous media. Vadose Zone J 2:444-475

54. Robinson DA, Lebron I, Kocar B, Phan K, Sampson M, Crook N, Fendorf S (2009) Time-lapse geophysical imaging of soil moisture dynamics in tropical deltaic soils: an aid to interpreting hydrological and geochemical processes. Water Resour Res 45(4):W00D32. https://doi.org/10.1029/2008WR006984 
55. Robinson DA, Lebron I, Querejeta Jl (2010) Determining soiltree-grass relationships in a California oak savanna using ecogeophysics. Vadose Zone J 3:528-536

56. Robinson DA, Abdu H, Lebron I, Jones SB (2012) Imaging of hillslope soil moisture wetting patterns in a semi-arid oak savanna catchment using time-lapse electromagnetic induction. J Hydrol 416:39-49

57. Ruffet C, Darot M, Guéguen Y (1995) Surface conductivity in rocks: a review. Surv Geophys 16:83-105

58. Sheets KR, Hendrickx JM (1995) Noninvasive soil water content measurement using electromagnetic induction. Water Res Res 10:2401-2409

59. Stroh JC, Archer S, Doolittle JA, Wilding L (2001) Detection of edaphic discontinuities with ground-penetrating radar and electromagnetic induction. Landsc Ecol 5:377-390

60. Sudduth KA, Kitchen NR, Wiebold WJ, Batchelor WD, Bollero GA, Bullock DG, Clay Thelen KD et al (2005) Relating apparent electrical conductivity to soil properties across the north-central USA. Comput Electron Agric 1:263-283

61. Taylor JC, Wood GA, Earl R, Godwin RJ (2003) Soil factors and their influence on within-field crop variability, part II: spatial analysis and determination of management zones. Biosyst Eng 4:441-453

62. Topp GC, Davis JL, Annan AP (1980) Electromagnetic determination of soil water content: measurements in coaxial transmission lines. Water Resour Res 16:574-582

63. Triantafilis J, Lesch SM (2005) Mapping clay content variation using electromagnetic induction techniques. Comput Electron Agric 1:203-237

64. United States salinity laboratory staff. 1954. Diagnosis and Improvement of Saline and Alkali Soils. U.S.D.A. Agricultural Handbook No. 60

65. von Hebel C, Matveeva M, Verweij E, Rademske P, Kaufmann MS, Brogi C, Vereecken H, Rascher U, van der Kruk J (2018) Understanding soil and plant interaction by combining ground-based quantitative electromagnetic induction and airborne hyperspectral data. Geophys Res Lett 45(15):7571-7579
66. Wang J, Fu B, Qiu Y, Chen L (2001) Soil nutrients in relation to land use and landscape position in the semi-arid small catchment on the loess plateau in China. J Arid Environ 4:537-550

67. Western AW, Blöschl G, Grayson RB (1998) Geostatistical characterisation of soil moisture patterns in the Tarrawarra catchment. J Hydrol 1-2:20-37

68. Williams BG, Hoey D (1987) The use of electromagnetic induction to detect the spatial variability of the salt and clay contents of soils. Soil Res 1:21-27

69. Williams RJ, Cook GD, Gill AM, Moore PHR (1999) Fire regime, fire intensity and tree survival in a tropical savanna in northern Australia. Aust J Ecol 1:50-59

70. Wuddivira MN, Camps-Roach G (2007) Effects of organic matter and calcium on soil structural stability. Eur J Soil Sci 58:722-727

71. Wuddivira MN, Ekwue El, Stone RJ (2010) Modelling slaking sensitivity to assess the degradation potential of humid tropic soils under intense rainfall. Land Degrad Dev. https://doi. org/10.1002/ldr.961

72. Wuddivira MN, Robinson DA, Lebron I, Bréchet $L$, Atwell $M$, De Caires S, Oatham M, Jones SB, Abdu H, Verma AK, Tuller M (2012) Estimation of soil clay content from hygroscopic water content measurements. Soil Sci Soc Am J 76:1529-1535

73. Xu M, Zhao Y, Liu G, Wilson GV (2006) Identification of soil quality factors and indicators for the Loess Plateau of China. Soil Sci. https://doi.org/10.1016/j.tsf.2005.08.100

74. Yemefack M, Rossiter DG, Njomgang R (2005) Multi-scale characterization of soil variability within an agricultural landscape mosaic system in southern Cameroon. Geoderma 1:117-143

Publisher's Note Springer Nature remains neutral with regard to jurisdictional claims in published maps and institutional affiliations. 